https://dx.doi.org/10.4314/ijs.v21i2.11

Ife Journal of Science vol. 21, no. 2 (2019)

\title{
ASSESSMENT OF WATER QUALITY OF OGUN RIVER IN SOUTHWESTERN NIGERIA
}

\author{
Awomeso, J.A., Ogundairo, E.S., *Taiwo, A.M., Idowu, O.A., Gbadebo, A.M., \\ Oyetunde, O.A. \\ College of Environmental Resources Management, Federal University of Agriculture, Abeokuta, Nigeria \\ *Corresponding author, email:taiwoademat@gmail.com, taiwoam@funaab.edu.ng
}

(Received: $27^{\text {th }}$ November, 2018; Accepted: $15^{\text {th }}$ May, 2019)

\section{ABSTRACT}

\begin{abstract}
The present study assessed the water quality of Ogun river in southwestern Nigeria. Forty water samples were collected from twenty monitoring stations along Ogun River Basin between April 2013 and January 2014. Water samples were analyzed for important physical and chemical parameters such as temperature, $\mathrm{pH}$, turbidity, total suspended solids (TSS), total dissolved solids (TDS), total solids (TS), electrical conductivity EC, dissolved oxygen (DO), silica, anions $\left(\mathrm{F}, \mathrm{Cl}, \mathrm{PO}_{4}^{3-}, \mathrm{NO}_{3}\right)$, hardness, alkalinity and metals $(\mathrm{Fe}, \mathrm{Pb}, \mathrm{Cd}, \mathrm{Na}, \mathrm{K})$ using the standard procedures. Data collected were subjected to simple descriptive (mean and standard deviation) and inferential statistics (Duncan Multiple Range Test, DMRT and Principal Component Analysis, PCA) using the Statistical Package for Social Sciences (SPSS, Windows' version 16.0). Results showed higher mean concentrations of turbidity $(49.7 \pm 13.0 \mathrm{NTU})$ and total suspended solids $(1205.2 \pm 4.7 \mathrm{mg} / \mathrm{L})$ than the permissible limits of the World Health Organization (WHO) in drinking water. The values of phosphate $(1.14 \pm 1.3 \mathrm{mg} / \mathrm{L}), \mathrm{Cd}(0.02 \pm 0.01 \mathrm{mg} / \mathrm{L})$ and $\mathrm{Pb}(0.33 \pm 0.05 \mathrm{mg} / \mathrm{L})$ were also observed at higher concentrations than the permissible standards of the WHO. The sources of pollution to Ogun River Basin identified by varimax rotated PCA were industrial effluents, runoff, fertilizer and dissolved salts.
\end{abstract}

Keyword: assessment, water quality, pollution, multivariate analysis, parameters

\section{INTRODUCTION}

Rivers and streams constitute the main inland water resources for domestic, industrial and irrigation purposes. It is therefore necessary to prevent any activities that can pollute them. The periodic monitoring and assessment of water quality are important steps in achieving an effective management and pollution control of surface water. The variances in water quality may be due to natural and anthropogenic activities. Natural sources of water pollution may emanate from bedrock weathering and erosion of materials into water bodies by rain or wind. Urban runoff was identified as one of the natural causes of water pollution (Izonfuo and Bariweni, 2001; Taiwo et al., 2011). The study of Taiwo et al. (2012) highlighted several anthropogenic activities that had negatively impacted surface water quality. These activities include industrial effluent discharge, oil spills, municipal and agricultural wastes. Recent studies had attributed activities such as food (locust beans) processing, textile making and dyeing, mining, poultry and abattoir wastes as major sources of water pollution (Taiwo et al., 2013; Ayantobo et al., 2014; Ojekunle et al.,
2014; Taiwo and Awomeso, 2017). Awomeso et al. (2010) reported deterioration of Lagos Lagoon water quality due to dumping of raw sewage.

The water quality of rivers in Nigeria are characterized by high concentrations of total suspended solids (Osibanjo et al., 2011), turbidity (Adefemi et al., 2007) and biological oxygen demand, (BOD) (Wakama et al., 2008), nutrients, e.g. phosphate, ammonia and nitrate (Olajire and Imeokparia, 2001), metals (Jaji et al., 2007), microbial contaminants (Taiwo, 2010) and organic chemicals e.g. pesticides (Ogunfowokan et al., 2006). The problems of high TSS in surface water include effects on fish growth and survival, nutrient enrichment, reduced sunlight penetration (required for photosynthesis of aquatic plants) and transportation of toxic substances (Schueler, 1997; Taiwo et al., 2011). The presence of heavy metals in surface water may pose potential risks to the environment and ecological system. Toxic metals such as $\mathrm{Pb}, \mathrm{Cd}, \mathrm{As}, \mathrm{Hg}$ and $\mathrm{Cr}$ may bioaccumulate in food chain and therefore initiate severe health problems including cancer, renal dysfunction, kidney and skeletal damage, 
neurological disorder, encephalopathy, anaemia and disturbance of cardiovascular (Jarup, 2003; Sireli et al., 2006; Olatunde et al., 2014). Nutrient enrichment of water body known as eutrophication may initiate severe problems to surface water in the aspect of destruction of spawning ground for aquatic lives, reduction of dissolved oxygen (DO) and impairment of water quality (Izonfuo and Bariweni, 2001). High BOD concentration in water body is an indicator of high organic loads with consequent effects on dissolved oxygen (Penn et al., 2006). Reduction in surface water DO usually influences water biology and abundance of aquatic organisms (Water Research Center, 2014). Turbid water may increase water temperature (thermal stratification), reduce photosynthetic ability of phytoplankton, decrease fish eggs' survival rate and interference of fish to find food (Alaska Department of Environmental Conservation, 2013). The problems of microbial contaminants are prevalent water-borne and water-related diseases (Awomeso et al., 2010). The main objective of this study is to assess the water quality of Ogun River Basin in southwestern Nigeria.

\section{MATERIALS AND METHODS The study Area}

Ogun River Basin (Ogun, Ofiki, Opeki and Oyan) covers a total area of $23,700 \mathrm{~km}^{2}$ and is located between latitude $6^{\circ} 33^{\prime}$ and $9^{\circ} \mathrm{N}$ and longitude $2^{\circ} 40^{\prime}$ and $3^{\circ} 45^{\prime} \mathrm{E}$ in the Rain Forest zone of
Nigeria. The climate of the study area is characterized by two seasons viz: wet (March -October) and dry (November to March) seasons. The annual rainfall ranges between 1250 and 1400 $\mathrm{mm}$ (Eruola et al., 2012), while the annual average temperature is $30^{\circ} \mathrm{C}$. Ogun River Basin is an important water source for domestic, commercial, industrial and agricultural purposes (Ojekunle et al., 2011). The major socio-economic activities in the study areas are farming, fishing, sand dredging and cloth dyeing. There are few industries located around Ogun river axis of Lagos State (Okeyode, 2012). Figure 1 shows the map of Ogun River Basin and the sampling locations.

\section{Water Collection and Analysis}

Forty water samples were collected from twenty monitoring stations along Ogun River Basin in Ogun, Ofiki, Opeki and Oyan between April 2013 and January 2014, covering rainy and dry seasons. Water samples were collected in prewashed 1 and $2 \mathrm{~L}$ plastic bottles. Samples for determination of metals were acidified at the point of collection with $2 \mathrm{~mL}$ nitric acid. Parameters determined were physical \{temperature, colour, turbidity, total suspended solids (TSS) and total solids (TS) $\}$ and chemical $\{\mathrm{pH}$, total dissolved solids (TDS), electrical conductivity (EC), dissolved oxygen (DO), anions ( $\left.\mathrm{F}, \mathrm{Cl}^{-}, \mathrm{PO}_{4}^{3-}, \mathrm{NO}_{3}\right)$, hardness, alkalinity, metals ( $\mathrm{Pb}, \mathrm{Cd}, \mathrm{Zn}, \mathrm{Na}$ and $\mathrm{K}$ ) parameters using the standard procedures (APHA, 1999). 


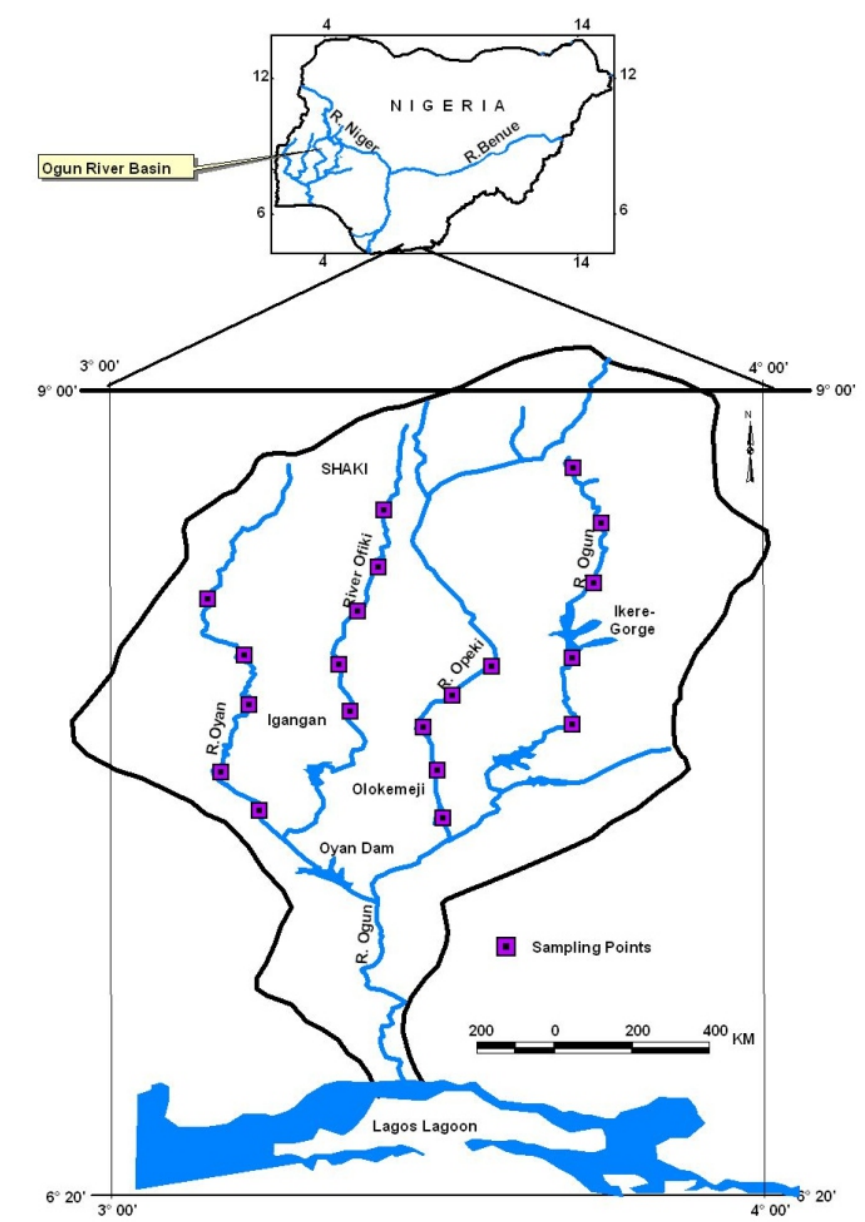

Figure 1: Map of Ogun River Basin showing the sampling points

Water temperature, $\mathrm{pH}$, TDS, EC and DO were determined in-situ. The collected water samples were transported to the Department of Environmental Management and Toxicology Laboratory for analysis of important water parameters using the standard methods (APHA, 1999). Water temperature, $\mathrm{pH}$, TDS and EC were determined electronically using the combined temperature/pH/TDS/EC meter (Combo Hi 98130, Hanna USA). Dissolved oxygen was measured using the DO meter (HachsensION, UK). TSS was determined gravimetrically, while TS was obtained by summing up the values of TDS and TSS. Colour and turbidity were determined using a UV-visible Spectrophotometer (Hach DR/4000, UK).

Chloride was determined by Mohr's silver nitrate method (Korkmaz, 2005). Dissolved silica $\left(\mathrm{SiO}_{2)}\right.$ was analyzed using the Heteropoly Blue method described in APHA (1999). Nitrate $\left(\mathrm{NO}_{3}\right)$ was measured using the sodium salicylate method (Ademoroti, 1996; Taiwo, 2010). Sulphate $\left(\mathrm{SO}_{4}^{2}\right)$ and fluoride were determined spectrophotometrically (Ademoroti, 1996). Metals (Fe, Pb, Cd) were determined by Atomic Absorption Spectrophotometry (Buck Scientific 200, USA) and Flame Photometry (Model 970, Jenway, EU) for $\mathrm{Na}$ and $\mathrm{K}$. Prior to measurement of metals, water samples were digested with concentrated $\mathrm{HNO}_{3}$ using the method described by Ayantobo et al. (2014).

All reagents used were of Analytical Grade (Sigma-Aldrich Chemie, GmbH, Germany). Blank samples were also analyzed to cancel the background effects of the extracting chemicals (Taiwo et al., 2014). The calibration of AAS instrument follows preparation of series of standards in the concentration range of $0-100 \mathrm{mg}$ $\mathrm{L}^{-1}$, to obtain the calibration curves.

\section{Statistical Analysis}

Data collected were subjected to simple descriptive (mean and standard deviation) and inferential (Duncan Multiple Range Test, DMRT, 
t-test and Principal Component Analysis, PCA) statistics using the Statistical Package for Social Science (SPSS) Windows version 16.0. PCA is a multivariate statistical tool that explains the statistical variance of chemical species measured at the receptor site in a number of original variances by a minimum number of significant components (Taiwo, 2013).

\section{RESULTS AND DISCUSSION}

The seasonal variations of Ogun River Basin water quality physical parameters at different Ogun River Basin are presented in Table S1 (in the supplementary information). The water temperature at the two seasons was generally lower than $29^{\circ} \mathrm{C}$. During the wet season, Oyan river showed higher concentrations of turbidity (166.3 $\pm 2.4 \mathrm{NTU})$, TSS $(1205.2 \pm 4.7 \mathrm{mg} / \mathrm{L})$ and TS $(1217.1 \pm 5.0 \mathrm{mg} / \mathrm{L})$. The values of turbidity and TSS were higher than the permissible levels in unpolluted water (Taiwo et al., 2013). Except in Ogun river, where the turbidity value $(5.77 \pm 5.83$ NTU) was slightly higher than the WHO standard of 5.0 NTU (WHO, 2011; Taiwo et al., 2013). Other rivers showed lower turbidity values during the dry season. The dry season values of TSS at the sampling sites were also higher than the normal TSS value often found in natural surface water indicating pollution of the Basin at all the sampling sites.

Table S2 (in the supplementary information) presents the site-based seasonal variations of chemical parameters of Ogun River Basin. The $\mathrm{pH}$ of water samples at all the sampling sites was neutral showing values ranging from $7.01 \pm 0.01$ (wet season) to $7.12 \pm 0.21$ (dry season). The DO concentrations were higher during the dry season than the wet season. At the two seasons, the mean DO values were generally greater than the minimum value of $5.0 \mathrm{mg} / \mathrm{L}$ that will support aquatic lives in natural water (Water Research Center, 2014). During the two seasons, the mean concentrations of EC $(<80 \mu \mathrm{S} / \mathrm{cm})$, TDS $(<60$ $\mathrm{mg} / \mathrm{L})$, total hardness $(<75 \mathrm{mg} / \mathrm{L})$, chloride $(<40$ $\mathrm{mg} / \mathrm{L})$, nitrate $(<2.0 \mathrm{mg} / \mathrm{L})$, sulphate $(<20.0$ $\mathrm{mg} / \mathrm{L})$ and silica $(<5.0 \mathrm{mg} / \mathrm{L})$ were within the permissible limits in natural water (Taiwo, 2010). At wet season, the highest fluoride value of $2.07 \pm 1.74 \mathrm{mg} / \mathrm{L}$ was observed in Ofiki river; while at dry season, the highest fluoride concentration $(1.68 \pm 0.08 \mathrm{mg} / \mathrm{L})$ was measured in Ogun river. The measured phosphate values from the monitored rivers were generally high at both wet and dry seasons. The data of metal concentrations of the River Basin is presented in Table S3 (in the supplementary information). At wet season, Oyan river had the highest concentrations of $\mathrm{Na}(13.47 \pm 0.29 \mathrm{mg} / \mathrm{L}), \mathrm{Fe}$ $(0.54 \pm 0.44 \mathrm{mg} / \mathrm{L}), \mathrm{Cd}(0.03 \pm 0.01 \mathrm{mg} / \mathrm{l})$ and $\mathrm{Pb}$ $(0.31 \pm 0.06 \mathrm{mg} / \mathrm{L})$. The dry season data showed the highest values of $\mathrm{K}, \mathrm{Fe}$ and $\mathrm{Pb}$ for the same river. $\mathrm{Fe}, \mathrm{Pb}$ and $\mathrm{Cd}$ concentrations at each monitoring site were generally higher than the World Health Organization permissible standards in drinking water (WHO, 2011).

The summary of Ogun River Basin water quality data is presented in Figures 2-5. The mean value of turbidity (49.69 $\pm 13.0 \mathrm{NTU})$ was higher than the WHO limit of 5.0 NTU (WHO, 2011). The mean concentrations of $\mathrm{pH}, \mathrm{EC}$, DO, total hardness, calcium hardness, magnesium hardness, nitrate and silica were within the normal values often found in surface water. However, the mean phosphate concentration observed in Ogun River Basin was extremely high. The combined average value of phosphate $(1.14 \pm 1.28 \mathrm{mg} / \mathrm{L})$ was about 40 times higher than the normal phosphate concentration in unpolluted surface water. The average concentration of fluoride in the River Basin was $1.45 \pm 0.92 \mathrm{mg} / \mathrm{L}$. The pooled mean value of $\mathrm{Cd}$ and $\mathrm{Pb}$ were found to be 19 and 7 times higher than the maximum permissible limits of 0.001 and $0.05 \mathrm{mg} / \mathrm{L}$, respectively (WHO, 2011). The mean concentration of Fe was within the WHO standard of $0.03 \mathrm{mg} / \mathrm{L}$ (WHO, 2011). $\mathrm{Na}$ and $\mathrm{K}$ values in the River Basin were generally less than $15 \mathrm{mg} / \mathrm{L}$. 
Awomeso et al.: Assessment of Water Quality of Ogun River

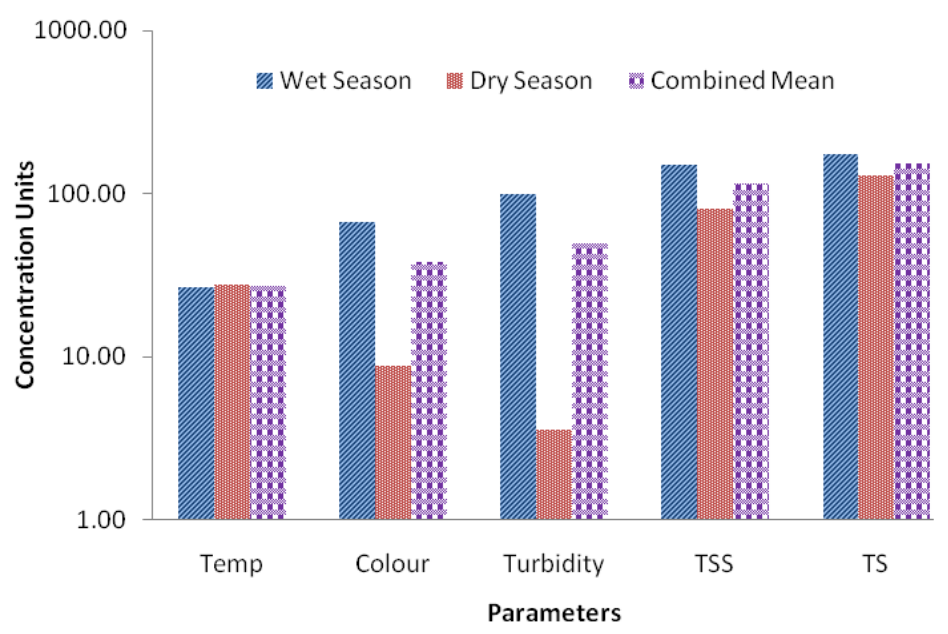

Figure 2: The average seasonal concentrations of physical water quality parameters of Ogun River Basin.Temp-temperature ( $\mathrm{C}$ ), colour (TCU), turbidity (NTU), TSS-total suspended solids (mg/L), TS-total solids (mg/L).

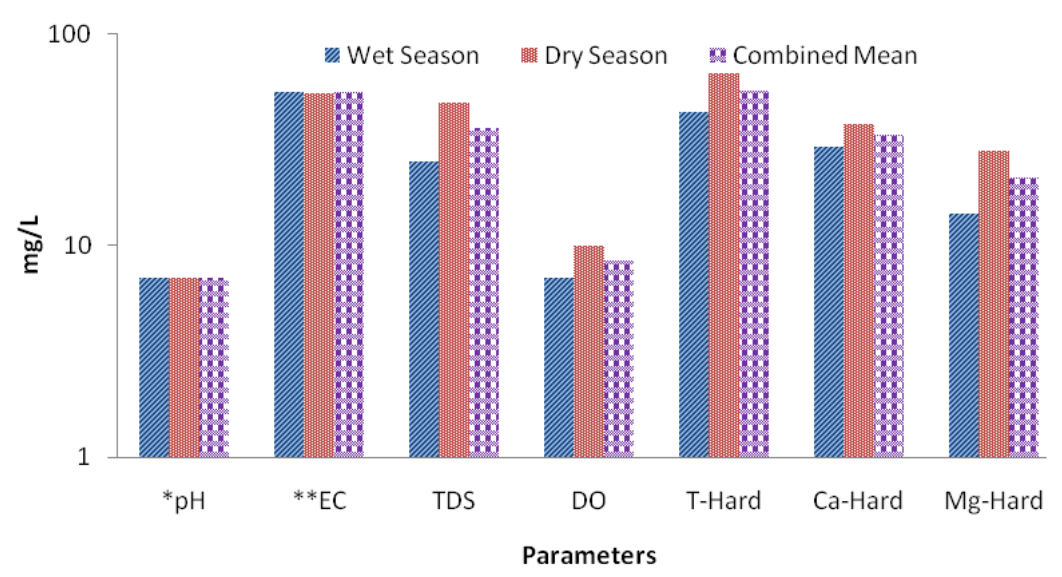

Figure 3: The average seasonal concentrations of important chemical water quality parameters of Ogun River Basin. ${ }^{*} \mathrm{pH}$ has no unit, ${ }^{* *}$ EC-electrical conductivity $(\mu \mathrm{S} / \mathrm{cm})$, TDS- total dissolved solids, T-Hard-total hardness, Ca-Hard-calcium hardness, Mg-Hard-magnesium hardness.

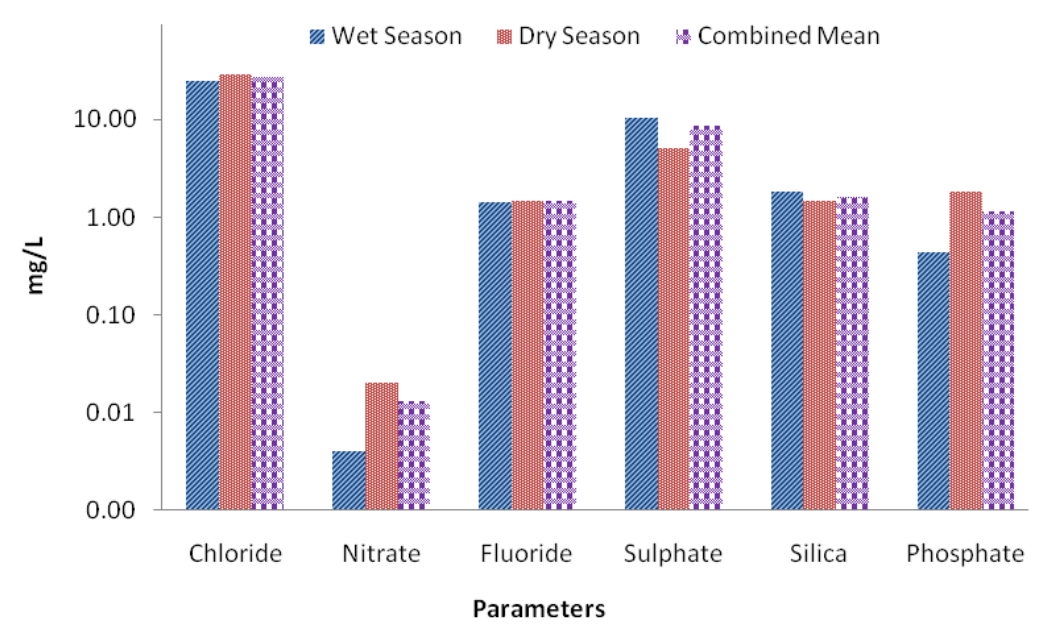

Figure 4: The mean seasonal variations of water anions of Ogun River Basin 


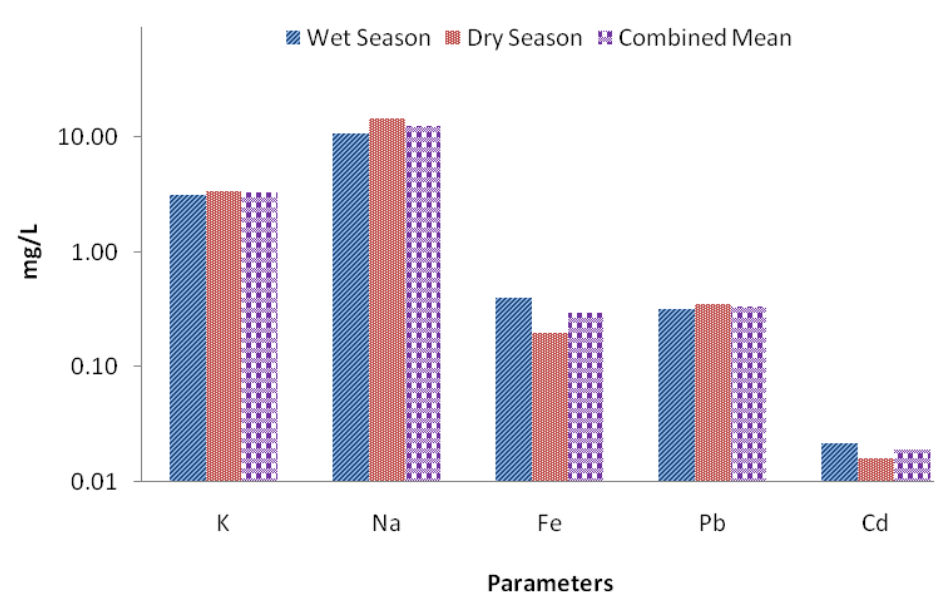

Figure 5: The mean seasonal concentrations of metals of Ogun River Basin

The principal component analysis data of Ogun River Basin is presented in Table 1. Four factors were identified by the model explaining $80 \%$ of the total variance. Factor 1 has high loading for $\mathrm{pH}$, TDS, calcium, magnesium, total hardness, $\mathrm{K}$, $\mathrm{Na}$ and $\mathrm{Pb}$. This factor may suggest an industrial source. Even though, the concentrations of most of the parameters explained by Factor 1 were found to be within the permissible limits; but the high value of $\mathrm{Pb}$ indicates anthropogenic emission. Emission sources of $\mathrm{Pb}$ in the environment are mainly from industries such as iron and steel, paints, batteries, petrochemicals, electroplating and smelting (Taiwo, 2013). Industrial effluents had been observed as an important source of pollution to surface water in Nigeria (Taiwo, 2012).

Factor 2 is characterized by significance for colour, turbidity, TS, TSS and dissolved silica. This factor may be linked to runoff of materials from point and non-point sources. During the rainfall, different materials including soil, leaves, solid and liquid wastes, pesticides and chemicals are washed into the surface water bodies (Izonfuo and
Bariweni, 2001; Taiwo et al., 2011). Anthropogenic sources of water pollution from runoff had been reported in many studies (Jaji et al., 2007; Mustapha, 2008; Taiwo, 2010; Kelly et al., 2012, Taiwo, 2012).

Factor 3 is loaded for colour, sulphate, fluoride and $\mathrm{Fe}$. This factor may be best described as fertilizer source. The fertilizer factor identified in component 3 might suggest the use of iron sulphate ( $\left.\mathrm{FeSO}_{4}\right)$ fertilizer (http://passel.unl.edu/pages/informationmodul e. $p$ h p ? i d i f o r m a t i o $n$ module $=1130447045 \&$ topicorder $=7 \&$ maxto $=7$ ) . Wastes from poultry farm activities and the use animal manures for soil amendment might also be responsible for high $\mathrm{Fe}$ and $\mathrm{SO}_{4}^{2-}$ concentrations in water (Fairchild et al., 2006). Factor 4 has high loadings for EC and chloride indicating a dissolved salt or a saline source. Dissolved salts in water bodies could be due to deposition of sea spray, urbanization and agriculture (Podmore, 2009). Cole and Ryan (2003) suggested that high EC in water might be attributed to sewage contamination. 
Table 1: PCA of Ogun River Basin

\begin{tabular}{|c|c|c|c|c|c|}
\hline \multicolumn{6}{|c|}{ Rotated Component Matrix ${ }^{a}$} \\
\hline & & & Compr & & \\
\hline & 1 & 2 & 3 & 4 & Communalities \\
\hline Temperature & .280 & -.555 & .252 & -.167 & .478 \\
\hline $\mathrm{pH}$ & .940 & -.256 & -.067 & .018 & .953 \\
\hline $\mathrm{DO}$ & .048 & -.951 & -.079 & -.026 & .914 \\
\hline EC & .067 & .384 & .103 & .776 & .765 \\
\hline Colour & -.269 & .681 & .617 & .179 & .949 \\
\hline Turbidity & -.133 & .960 & .189 & -.016 & .976 \\
\hline TS & .168 & .901 & .274 & .191 & .952 \\
\hline TDS & .733 & -.549 & .040 & .322 & .945 \\
\hline TSS & .044 & .939 & .253 & .130 & .965 \\
\hline Total Hardness & .962 & .005 & .099 & .032 & .936 \\
\hline Ca Hardness & .758 & .078 & .025 & -.139 & .601 \\
\hline Mg Hardness & .806 & -.068 & .131 & .352 & .795 \\
\hline Chloride & .088 & -.039 & .040 & .592 & .361 \\
\hline Nitrate & -.706 & -.524 & -.051 & .093 & .784 \\
\hline Fluoride & -.050 & -.009 & .824 & .216 & .728 \\
\hline Sulphate & -.093 & .227 & .856 & .092 & .802 \\
\hline Silica & -.051 & .686 & .007 & -.602 & .836 \\
\hline $\mathrm{K}$ & .966 & -.111 & .011 & .161 & .971 \\
\hline Phosphate & .448 & -.855 & -.071 & .210 & .981 \\
\hline $\mathrm{Na}$ & .859 & -.400 & -.071 & .143 & .924 \\
\hline $\mathrm{Fe}$ & .175 & .207 & .724 & -.195 & .636 \\
\hline $\mathrm{Pb}$ & .688 & -.249 & -.123 & -.284 & .632 \\
\hline $\mathrm{Cd}$ & -.593 & -.172 & .296 & -.238 & .526 \\
\hline$\%$ Variance & 31 & 28 & 12 & 9 & $(80 \%)$ \\
\hline Sources & Industry & Run-off & Fertilizer & Dissolved Salt & \\
\hline
\end{tabular}

DO- Dissolved Oxygen, EC-Electrical Conductivity, TS-Total Solids, TDS-Total Dissolved Solids, TSS-Total Suspended Solids

It was generally observed that during the wet season, there were higher significant $(p<0.05)$ concentrations of colour, turbidity, TSS, TS, Fe and $\mathrm{Na}$. This might be attributed to runoff of pollutants from diverse point and non-point sources (Taiwo, 2012; Li et al., 2015; Mezgebe et al., 2015). Water quality parameters including temperature, DO, TDS, total hardness, Ca hardness, $\mathrm{Mg}$ hardness, $\mathrm{PO}_{4}^{3-}$ were significantly higher $(\mathrm{p}<0.05)$ during the dry season. Apart from temperature, other water parameters were expected to show higher concentrations during the wet season (Athuman, 2012). But these parameters were measured at higher values during the dry season. This may therefore suggest anthropogenic influence from industry, agriculture, abattoir activities, textile dyeing, washing and bush burning (Dike et al., 2010;
Ubwa et al., 2013; Ojekunle et al., 2014). In the South-east Asia, biomass burning had been found to be the greatest contributor to atmospheric fluxes of nutrients with subsequent effects on water quality (Balasubra-manian and Qian, 2004; Sundarambal et al., 2010). There were no significant $(p>0.05)$ seasonal variations in the concentrations of $\mathrm{pH}, \mathrm{EC}, \mathrm{Cl}^{-}, \mathrm{NO}_{3}, \mathrm{SO}_{4}^{2-}, \mathrm{SiO}_{2}$, $\mathrm{K}, \mathrm{Pb}$ and $\mathrm{Cd}$ in water samples.

The high mean values of TSS indicated that the River Basin is polluted. The past studies from Ogun river had reported similar high values of colour, turbidity and TSS (Jaji et al., 2007; Etim and Adie, 2012). A study had shown that turbidity values above 1,000 NTU (for months) in water bodies can cause fish death (Denby et al., 1987). TSS value above $80 \mathrm{mg} / \mathrm{L}$ is also dangerous to 
aquatic organisms (Taiwo, 2013). Colour, turbidity and TSS could impact water quality in many ways among which are: (1) reduction of water clarity, which is very dangerous to divers. (2) reduction in aesthetic quality of water bodies with impacts on recreation and tourism. (3) contribution to outbreak of water-borne diseases by shielding the microbes associated with organic portion (Wilson, 2010).

Phosphate values obtained in this study was higher than the value that is normally found in natural surface water. In uncontaminated lake, phosphate value is measured usually between the range of 0.01 and $0.03 \mathrm{mg} / \mathrm{L}$ (Water Research Center, 2014). Phosphate value above $0.10 \mathrm{mg} / \mathrm{L}$ could accelerate plant's growth or algae bloom with subsequent ecological and environmental problems (Water Research Center, 2014). Phosphate value greater than $100 \mu \mathrm{g} / \mathrm{L}$ may interfere with coagulation process (Fadiran et al., 2008). The high concentration of phosphate obtained in this River Basin may have negative impacts on water treatment processes and thereby affects water supply.

At the lower course, Ogun River Basin was abstracted for public water supply in Abeokuta. The Waterworks is a source of potable water to at least one hundred and eighty thousand residents (Ufoegbune et al., 2010). The mean value of phosphate concentration observed in this study was higher than the value of $0.17 \pm 0.01 \mathrm{mg} / \mathrm{L}$ measured in New Calabar river (Abu and Egenonu, 2008). However, studies from northern parts of Nigeria had measured higher phosphate values ranging from 3.8 to $16 \mathrm{mg} / \mathrm{L}$ (Dike et al., 2010; Ubwa et al., 2013). Comparing this study with the previous study of Ogun river by Jaji et al. (2007) showed that the value of phosphate had increased by a factor of 25. This shows that human activities leading to phosphate pollution around the River Basin had also increased. The major activities that could increase phosphate concentration in surface water are industrial effluent discharge wastes and disposal of municipal, agricultural and abattoir wastes (Taiwo et al., 2011). The high values of phosphate concentrations observed in Jakara river (Kano) and Gboko Stream (Benue) had been attributed to abattoir wastes discharge into the surface water bodies (Dike et al., 2010; Ubwa et al., 2013).

The average fluoride value of Ogun River Basin was higher than the range value of $0.90-1.2 \mathrm{mg} / \mathrm{L}$ that could result into mild fluorosis, a condition characterized by staining and pitting of the teeth (WHO, 2004; 2015). The presence of $\mathrm{Cd}$ and $\mathrm{Pb}$ at concentrations higher than the permissible standards may pose health risk on humans and animals. The concentrations of $\mathrm{Cd}$ and $\mathrm{Pb}$ in water and/or food are of major health concerns due to the fact that these metals have no known physiological functions in human body (Hou et al., 2013). The health effects of $\mathrm{Cd}$ and $\mathrm{Pb}$ had been described explicitly by Jarup (2003).

\section{CONCLUSION}

This study had examined the water quality of Ogun River Basin. The study revealed high concentrations of colour, turbidity, total suspended solids, phosphates, $\mathrm{Cd}$ and $\mathrm{Pb}$. These parameters had values greater than the permissible limits allowed by the World Health Organization (WHO). The pooled mean concentration of Fe was found to be within the value of $0.30 \mathrm{mg} / \mathrm{L}$ permitted by the WHO. The study also revealed higher significant concentrations of parameters such as turbidity, TSS, TS, Fe and Na during the wet season, while temperature, DO, TDS, hardness (total, $\mathrm{Ca}$ and $\mathrm{Mg}$ ), $\mathrm{PO}_{4}^{3-}$ were higher during the dry season. There were no seasonal variations in concentrations of $\mathrm{pH}, \mathrm{EC}, \mathrm{Cl}, \mathrm{NO}_{3}$, $\mathrm{SO}_{4}^{2-}, \mathrm{SiO}_{2}, \mathrm{~K}, \mathrm{~Pb}$ and $\mathrm{Cd}$. The principal component analysis revealed four major sources of pollutants, which include industry, runoff, fertilizer and dissolved salts. The study had shown that Ogun River Basin water quality had been deteriorated as a result of human activities.

\section{ACKNOWLEDGEMENTS}

The authors appreciated the assistance rendered Mr. Abulumen, O. of Department of Water Resources and Agrometeorology, and Mrs. Soriola, O. of Department of Environmental Management and Toxicology, Federal University of Agriculture, Abeokuta during the laboratory analysis.

\section{COMPETING INTERESTS}

The authors declare no competing interests. 


\section{REFERENCES}

Abu GO, Egenonu C. 2008. The current pollution status of the new Calabar River in the Niger Delta region of Southern Nigeria: A survey of antibiogram profiles of its bacterial isolates. African Journal of Environmental Science and Technology 2(6): 134-141.

Adefemi OS, Asaolu SS, Olaofe O. 2007. Assessment of the physico-chemical status of water samples from major dams in Ekiti State, Nigeria. Pakistan Journal of Nutrition 6 (6): 657-659.

Ademoroti CMO. 1996. Standard methods for water and effluents analysis. Foludex Press Ltd., Ibadan. Pp.32-118.

APHA.1999.Standard Methods for the Examination of Water and Wastewater. American Public Health Association, American Water Works Association and Water Pollution Control Federation, Washington, DC.

Athuman CB. 2012. Seasonal surficial distribution of water quality parameters at Lake Nyamagoma, Western Tanzania. International Journal of Applied Science and Technology 2(2): 18-25.

Awomeso JA, Taiwo AM, Gbadebo AM, Adenowo JA. 2010.Studies on the pollution of water body by textile industry effluents in Lagos, Nigeria. Journal of Applied Science in Environmental Sanitation 5 (4): 353-359,

Ayantobo OO, Awomeso JA, Oluwasanya GO, Bada BS, Taiwo AM. 2014. Non-cancer human health risk assessment from exposure to heavy metals in surface and groundwater in Igun Ijesha, Southwest Nigeria. American Journal of Environmental Sciences 10(3): 301-311.

Balasubramanian R, Qian WB. 2004. Characterization and source identification of airborne trace metals in Singapore. Journal of Environmental Monitoring 6(10): 813-818.

Cole JM, Ryan MC 2003. Arsenic source and fate at a village drinking water supply in Mexico and its relationship to sewage contamination. In: J Bundschuh, P Bhattacharya, Chandrasekharam (Eds.):
Proc. Natural Arsenic in Groundwater; Occurrence, Remediation and Management. London: Taylor \& Francies Group, pp. 67-71.

Denby L, Koenings J, LaPerrire J. 1987.Effects of Turbidity in Fresh Waters of Alaska. Journal of Fisheries Management 7:18-13.

Dike NI, Oniye SJ, Ajibola VO, Ezealor AU. 2010. Nitrate and phosphate levels in River Jakara,

Kano State, Nigeria. Science World Journal 5(3): 23-27.

Eruola AO, Ufeogbune GC, Eruola AA, Idowu OA, Oluwasanya GO, Ede VA. 2012. Effect of Climate Change on Water Balance of Lower Ogun River Basin. Special Publication of the Nigerian Association of Hydrological Sciences 360367.

Etim EU, Adie GU. 2012. Assessment of qualities of surface water, sediments and aquatic fish from selected major Rivers in SouthWestern Nigeria. Research Journal of Environmental and Earth Sciences 4(12): 1045-1051.

Fadiran AO, Dlamini SC, Mavuso A. 2008. A comparative study of the phosphate levels in some surface and ground water bodies of Swaziland. Bulletin of the Chemical Society of Ethiopia, 22(2): 197-206

Fairchild BD, Batal AB, Ritz CW, Vendrell PF. 2006. Effect of drinking water iron concentration on broiler performance. The Journal of Applied Poultry Research 15(4):511-517.

Hou S, Yuan L, Jin P, Ding B, Qin N, Li L, Deng Y. 2013. A clinical study of the effects of lead poisoning on the intelligence and neurobehavioral abilities of children. Theoretical Biological and Medical Model 10(1): 13.

Izonfuo LWA, Bariweni AP. 2001. The effect of urban runoff water and human activities on some physico-chemical parameters of the Epie Creek in the Niger Delta. Journal of Applied Science and Environmental Management 5 (1): 47-55.

Jaji MO, Bamgbose O, Odukoya OO, Arowolo TA. 2007. Water quality assessment of Ogun River, south west Nigeria. 
Environmental Monitoring and Assessment 133(1-3): 473-482.

Jarup L. 2003. Hazards of heavy metal contamination. British Medical Bulletin 68(1): 167-182.

Kelly WR, Panno SV, Hackley K. 2012. The sources, distribution, and trends of chloride in the waters of Illinois. Illinois State Water Survey Bulletin 74. 53p.

Korkmaz D. 2005. Precipitation titration: Determination of Chloride by the Mohr Method. Methods 2: 4:1-6.

Li D, Wan J, Ma Y, Wang Y, Huang M, Chen Y. 2015. Stormwater runoff pollutant loading distributions and their correlation with rainfall and catchment characteristics in a rapidly industrialized city. PloSOne 10(3): e0118776.

Mezgebe K, Gebrekidan A, Hadera A, Weldegebriel Y. 2015. Assessment of physico-chemical

parameters of TsaedaAgam River in Mekelle City, Tigray, Ethiopia. Bulletin of the Chemical Society of Ethiopia 29(3):377-385.

Mustapha MK. 2008. Assessment of the water quality of Oyun Reservoir, Offa, Nigeria, using selected physico-chemical parameters. Turkish Journal of Fisheries and Aquatic Sciences, 8: 309-319. www.trjfas.org/pdf/issue_8_2/309_319.

Ogunfowokan AO, Torto N, Adenuga A, Okoh EK. 2006. Survey of levels of phthalate ester plasticizers in a sewage lagoon effluent and a receiving stream. Environmental Monitoring and Assessment 118: 457-480.

Ojekunle ZO, Ojo KO, Idowu OA, Martins O, Oluwasanya GO, Ojekunle VO. 2011. Evaluation of sustainable water demand in a coastal environment using WEAP Model. Proceedings of the Environmental Management Conference, Federal University of Agriculture, Abeokuta, Nigeria. 539-552.

Ojekunle ZO, Ufoegbune GC, Oyebamiji FF, Sangowusi RO, Taiwo AM, Ojekunle VO. 2014. Assessment of the effect of commercial activities on the surface water quality of Ogun River, Nigeria. Merit Research Journal 2 (9): 196-204.
Okeyode IC. 2012. Radiogenic heat production due to natural radionuclides in the sediments of

Ogun River, Nigeria. Journal of Environmental Earth Science 2: 196-207.

Olajire AA, Imeokparia FE. 2001. Water quality assessment of Osun River: Studies on inorganic

nutrients. Environmental Monitoring Assessment 69:17-28.

Olatunde KA.,Arowolo TA, Bada BS, Taiwo AM, Ojekunle ZO. 2014. Distribution and enrichment of metals in sediments of the Ogun River within Abeokuta, southwestern Nigeria. African Journal of Aquatic Science 39(1): 17-22.

Osibanjo O, Daso AP., Gbadebo AM. 2011. The impact of industries on surface water quality of River Ona and River Alaro in Oluyole Industrial Estate, Ibadan, Nigeria. African Journal of Biotechnology 10 (4): 696-702.

Penn MR, Pauer JJ, Mihelcic JR. 2006. Biochemical oxygen demand. Environmentaland

Ecological Chemistry 2:1-8. http://www.eolss.net/samplechapters/c06/e6-13-04-03.pdf.

Podmore C. 2009. Irrigation salinity-causes and impacts. Primefact 937 (1): 1-4.

Schueler T. (Ed.). 1997. Comparison of forest, urban and agricultural streams in North Carolina.

Watershed Protection and Technology 2(4): 503-506.

Sireli UT, Göncüoğlu M, Yıldırım Y, Gücükoğlu A, Çakmak Ö. 2006. Assessment of heavy metals (cadmium and lead) in vacuum packaged smoked fish species (mackerel, Salmosalar and Oncorhynhusmykiss) marketed in Ankara (Turkey). Ege University Journal of Fisheries and Aquatic Sciences 23: 353356.

Sundarambal P, Balasubramanian R, Tkalich P, He J. 2010. Impact of biomass burning on ocean water quality in Southeast Asia through atmospheric deposition: field observations. Atmospheric Chemistry and Physics 10(23): 11323-11336. 
Taiwo AM. 2010. Environmental impact of poultry farm operations on Alakata Stream at Isolu in Abeokuta, Nigeria. Unpublished Master's Thesis. University of Agriculture, Abeokuta.108 p.

Taiwo AM, Adeogun AO, Olatunde KA, Adegbite KI. 2011. Analysis of groundwater quality of hand-dug wells inperi-urban areas of Obantoko, Abeokuta, Nigeria for selected physico-chemical parameters. Pacific Journal of Science and Technology, 12 (1): 527-534. www.akamaiuniversity.us /PJST12_1_527.pdf

Taiwo AM, Bamgbose O, Olujimi OO, Arowolo TA. 2012. Surface water quality monitoring in

Nigeria: Situational analysis and future management strategy. In: Water Quality Monitoring and Assessment, Dr.Voudouris (Ed.), ISBN: 978-953-510486-5, INTECH

http://www.intechopen.com/books/waterqualit $\mathrm{y}$-monitoring-and-assessment/surfacewater-quality-monitoring-in-nigeriasituational-analysis-andfuture management-strategy

Taiwo AM. 2013. Receptor modelling of industrial air pollutants (Doctoral dissertation,

University of Birmingham). 408p.

Taiwo AM, Arowolo TA, Adekunle IM, Adetunji MT. 2013. Evaluating the environmental impacts of poultry farming on stream water quality: A study from Abeokuta, Nigeria. Environmental Quality Management 22 (4): 79-93.

Taiwo AM, Beddows DCS, Shi Z, Harrison RM. 2014. Mass and number size distributions of particulate matter components: Comparison of an industrial site and an urban background site. Science of the Total Environment 475:29-38

Taiwo AM, Awomeso JA. 2017. Assessment of trace metal concentration and health risk of artisanal gold mining activities in Ijeshaland, Osun State Nigeria- Part 1. Journal of Geochemical Exploration 177:1-10

Ubwa ST, Atoo GH, Offem JO, Abah J, Asemave K. 2013. An assessment of surface water pollution status around Gboko abattoir. African Journal of Pure and Applied Chemistry7 (3): 131-138.

Ufoegbune GC, Eruola AO, Awomeso JA, Idowu OA. 2010. Spatial analysis of municipal water

supply in Abeokuta metropolis, South western Nigeria. Journal of Geography and Regional Planning 3(7): 169-176.

USEPA (United States Environmental Protection Agency). 1986.Quality criteria for water.

Office of water Regulation and standards, Washington dc, usepa-40015-86-256 pp.

USEPA. 2009.Sampling and analysis of waters, wastewaters, soils and wastes. Industrial Waste

Resource Guidelines (IWRG), Environment Protection (Industrial Waste Resource) Regulations 2009, Publication IWRG701.

Water Research Center. 2014. Phosphorus and water quality. http: / / waterresearch.net/index. $\mathrm{php} / \mathrm{phosphates.}$ Accessed: 20/4/2016.

WHO. 2004. Fluoride in Drinking-water. Background document for development of WHO

Guidelines for Drinking-water Quality WHO/SDE/WSH/03.04/96.

WHO. 2011. Guidelines for drinking-water quality, fourth edition. Water Sanitation

Healthhttp://www.who.int/water_sanita tion_health/publications/2011/dwq_gui delines/en

WHO. 2015. Water-related diseases. Water Sanitation Health. http://www.who.int/ water_sanitation_health/ $\mathrm{d}$ is e a s e s/fluorosis/en/. Accessed:04/08/2015.

Wilson PC. 2010. Water quality notes: Water clarity (turbidity, suspended solids, and color).

University of Florida, Institute of Food and Agricultural Sciences (IFAS) and the Florida Cooperation Extension Service, Gainesville, FL, 32611. 
Awomeso et al.: Assessment of Water Quality of Ogun River

Table S2: Seasonal variations of Ogun River Basinwater quality chemical parameters

\begin{tabular}{|c|c|c|c|c|c|c|c|c|c|}
\hline \multirow[t]{3}{*}{ Parameters } & \multirow[t]{3}{*}{ Statistics } & \multicolumn{8}{|c|}{ Sampling locations } \\
\hline & & \multicolumn{4}{|c|}{ Wet season } & \multicolumn{4}{|c|}{ Dry season } \\
\hline & & Ogun & Ofiki & Opeki & Oyan & Ogun & Ofiki & Opeki & Oyan \\
\hline \multirow[t]{4}{*}{$\mathrm{pH}$} & Mean & $7.01^{\mathrm{a}}$ & $7.07^{\mathrm{a}}$ & $7.08^{\mathrm{a}}$ & $7.08^{\mathrm{a}}$ & $7.06^{\mathrm{a}}$ & $7.08^{\mathrm{a}}$ & $7.02^{\mathrm{a}}$ & $7.12^{\mathrm{a}}$ \\
\hline & $\mathrm{SD}$ & 0.01 & 0.04 & 0.04 & 0.02 & 0.19 & 0.18 & 0.19 & 0.21 \\
\hline & Range & $7.00-7.04$ & $7.02-7.11$ & $7.03-7.13$ & $7.05-7.09$ & $6.93-7.37$ & $6.91-7.36$ & $6.89-7.34$ & $6.91-7.35$ \\
\hline & WHO & $6.5-8.5$ & $6.5-8.5$ & $6.5-8.5$ & $6.5-8.5$ & $6.5-8.5$ & $6.5-8.5$ & $6.5-8.5$ & $6.5-8.5$ \\
\hline $\mathrm{DO}(\mathrm{mg} / \mathrm{L})$ & $\begin{array}{l}\text { Mean } \\
\text { SD } \\
\text { Range }\end{array}$ & $\begin{array}{c}6.97^{\mathrm{a}} \\
0.01 \\
6.98-6.99\end{array}$ & $\begin{array}{c}7.41^{\mathrm{a}} \\
0.05 \\
7.32-7.45\end{array}$ & $\begin{array}{c}7.07^{\mathrm{a}} \\
0.53 \\
6.16-7.42\end{array}$ & $\begin{array}{c}7.02^{\mathrm{a}} \\
0.51 \\
6.20-7.46\end{array}$ & $\begin{array}{c}10.18^{\mathrm{b}} \\
0.26 \\
9.73-10.40\end{array}$ & $\begin{array}{c}10.10^{\mathrm{b}} \\
0.36 \\
9.70-10.50\end{array}$ & $\begin{array}{c}10.01^{\mathrm{b}} \\
0.20 \\
9.71-10.25\end{array}$ & $\begin{array}{c}10.12^{\mathrm{b}} \\
0.23 \\
9.72-10.30\end{array}$ \\
\hline \multirow[t]{2}{*}{$\mathrm{EC}(\mu \mathrm{S} / \mathrm{cm})$} & $\begin{array}{l}\text { WHO } \\
\text { Mean } \\
\text { SD }\end{array}$ & $\begin{array}{c}5 \\
50.33^{c} \\
0.22\end{array}$ & $\begin{array}{c}5 \\
73.07^{\mathrm{f}} \\
2.92\end{array}$ & $\begin{array}{c}5 \\
63.48^{\mathrm{b}} \\
0.36\end{array}$ & $\begin{array}{c}5 \\
26.80^{\mathrm{a}} \\
1.76\end{array}$ & $\begin{array}{c}5 \\
38.89^{\mathrm{b}} \\
5.77\end{array}$ & $\begin{array}{c}5 \\
57.25^{\mathrm{d}} \\
4.99\end{array}$ & $\begin{array}{c}5 \\
64.63^{\mathrm{e}} \\
3.77\end{array}$ & $\begin{array}{c}5 \\
50.49^{c} \\
0.25\end{array}$ \\
\hline & $\begin{array}{l}\text { Range } \\
\text { WHO }\end{array}$ & $\begin{array}{c}50.0-50.60 \\
1000\end{array}$ & $\begin{array}{c}68.43-76.20 \\
1000\end{array}$ & $\begin{array}{c}63.00-64.0 \\
1000\end{array}$ & $\begin{array}{c}25.00-29.50 \\
1000\end{array}$ & $\begin{array}{c}32.53-46.40 \\
1000\end{array}$ & $\begin{array}{c}53.40-64.05 \\
1000\end{array}$ & $\begin{array}{c}60.20-70.60 \\
1000\end{array}$ & $\begin{array}{c}50.20-50.80 \\
1000\end{array}$ \\
\hline \multirow[t]{2}{*}{ TDS (mg/L) } & $\begin{array}{l}\text { Mean } \\
\text { SD }\end{array}$ & $\begin{array}{c}23.53^{a} \\
0.54\end{array}$ & $\begin{array}{c}34.78^{\mathrm{bc}} \\
1.32\end{array}$ & $\begin{array}{c}29.9 \mathrm{bc} \\
0.69\end{array}$ & $\begin{array}{c}11.92^{\mathrm{a}} \\
0.42\end{array}$ & $\begin{array}{c}42.46^{\mathrm{cd}} \\
18.86\end{array}$ & $\begin{array}{c}59.26^{\mathrm{d}} \\
21.27\end{array}$ & $\begin{array}{c}43.04^{\mathrm{cd}} \\
17.72\end{array}$ & $\begin{array}{c}45.30^{\mathrm{cd}} \\
17.37\end{array}$ \\
\hline & Range & $22.70-24.20$ & $32.80-36.40$ & $28.95-30.90$ & $11.56-12.60$ & $29.30-74.30$ & $29.00-74.60$ & $29.10-73.20$ & $29.20-74.10$ \\
\hline \multirow[t]{3}{*}{ T-Hard.(mg/L) } & $\begin{array}{l}\text { WHO } \\
\text { Mean }\end{array}$ & $\begin{array}{c}500 \\
48.00^{\mathrm{ab}}\end{array}$ & $\begin{array}{c}500 \\
56.00^{\mathrm{ab}}\end{array}$ & $\begin{array}{c}500 \\
46.25^{\mathrm{ab}}\end{array}$ & $\begin{array}{c}500 \\
22.75^{\mathrm{a}}\end{array}$ & $\begin{array}{c}500 \\
60.40^{\mathrm{b}}\end{array}$ & $\begin{array}{c}500 \\
73.80^{\mathrm{b}}\end{array}$ & $\begin{array}{c}500 \\
61.80^{\mathrm{b}}\end{array}$ & $\begin{array}{c}500 \\
65.00^{\mathrm{b}}\end{array}$ \\
\hline & $\begin{array}{c}\text { SD } \\
\text { Range }\end{array}$ & $\begin{array}{c}3.54 \\
45.0-54.0\end{array}$ & $\begin{array}{c}0.71 \\
55.0-57.0\end{array}$ & $\begin{array}{c}0.83 \\
45.0-47.0\end{array}$ & $\begin{array}{c}3.11 \\
20.0-28.0\end{array}$ & $\begin{array}{c}29.01 \\
36.0-107.0\end{array}$ & $\begin{array}{c}31.92 \\
33.0-108.0\end{array}$ & $\begin{array}{c}26.36 \\
34.0-105.0\end{array}$ & $\begin{array}{c}25.89 \\
35.0-106.0\end{array}$ \\
\hline & WHO & 150 & 150 & 150 & 150 & 150 & 150 & 150 & 150 \\
\hline $\mathrm{Ca}(\mathrm{mg} / \mathrm{L})$ & $\begin{array}{l}\text { Mean } \\
\text { SD } \\
\text { Range }\end{array}$ & $\begin{array}{c}36.75^{\mathrm{b}} \\
0.15 \\
35.0-39.0\end{array}$ & $\begin{array}{c}38.00^{\mathrm{b}} \\
0.71 \\
37.0-39.0\end{array}$ & $\begin{array}{c}26.75^{\mathrm{ab}} \\
3.11 \\
24.0-32.0\end{array}$ & $\begin{array}{c}16.25^{\mathrm{a}} \\
2.28 \\
14.0-20.0\end{array}$ & $\begin{array}{c}35.20^{\mathrm{b}} \\
15.51 \\
24.0-60.0\end{array}$ & $\begin{array}{c}40.20^{\mathrm{b}} \\
17.34 \\
21.0-59.0\end{array}$ & $\begin{array}{c}38.20^{\mathrm{b}} \\
22.02 \\
22.0-67.0\end{array}$ & $\begin{array}{c}36.40^{\mathrm{b}} \\
14.22 \\
23.0-58.0\end{array}$ \\
\hline \multirow[t]{4}{*}{$\mathrm{Mg}(\mathrm{mg} / \mathrm{L})$} & $\begin{array}{l}\text { WHO } \\
\text { Mean }\end{array}$ & $12.25^{\mathrm{ab}}$ & $22.25^{\mathrm{bc}}$ & $22.00^{\mathrm{bc}}$ & $0.75^{\mathrm{a}}$ & $23.20^{\mathrm{bc}}$ & $32.80^{c}$ & $28.20^{c}$ & $28.40^{c}$ \\
\hline & SD & 1.48 & 4.71 & 0.71 & 0.15 & 11.69 & 15.74 & 12.95 & 13.01 \\
\hline & Range & $10.00-14.00$ & $18.00-30.00$ & $21.00-23.00$ & $0.60-1.00$ & $10.00-38.00$ & $10.00-49.00$ & $11.00-47.00$ & $12.00-48.00$ \\
\hline & WHO & 0.20 & 0.20 & 0.20 & 0.20 & 0.20 & 0.20 & 0.20 & 0.20 \\
\hline \multirow[t]{4}{*}{$\mathrm{Cl}^{-}(\mathrm{mg} / \mathrm{L})$} & Mean & $21.75^{\mathrm{a}}$ & $25.08^{\mathrm{a}}$ & $28.50^{\mathrm{a}}$ & $24.25^{\mathrm{a}}$ & $27.80^{\mathrm{a}}$ & $33.80^{\mathrm{a}}$ & $25.00^{\mathrm{a}}$ & $28.20^{\mathrm{a}}$ \\
\hline & SD & 1.09 & 12.62 & 4.92 & 0.83 & 15.01 & 10.13 & 9.08 & 7.95 \\
\hline & Range & $20.00-23.00$ & $3.30-34.00$ & $25.00-37.00$ & $23.00-25.00$ & $14.00-50.00$ & $24.00-49.00$ & $16.00-38.00$ & $18.00-40.00$ \\
\hline & WHO & 250 & 250 & 250 & 250 & 250 & 250 & 250 & 250 \\
\hline \multirow[t]{3}{*}{$\mathrm{F}^{-}(\mathrm{mg} / \mathrm{L})$} & Mean & $1.42^{\mathrm{a}}$ & $2.07^{\mathrm{b}}$ & $1.38^{\mathrm{b}}$ & $0.84^{a}$ & $1.68^{\mathrm{b}}$ & $1.46^{\mathrm{b}}$ & $1.30^{\mathrm{ab}}$ & $1.42^{\mathrm{b}}$ \\
\hline & SD & 0.08 & 1.74 & 0.01 & 0.10 & 0.08 & 0.17 & 0.10 & 0.08 \\
\hline & Range & $1.30-1.50$ & $0.42-5.00$ & $1.37-1.39$ & $0.70-0.95$ & $1.60-1.80$ & $1.30-1.70$ & $1.20-1.40$ & $1.30-1.50$ \\
\hline Nitrate $(\mathrm{mg} / \mathrm{L})$ & $\begin{array}{l}\text { WHO } \\
\text { Mean } \\
\text { SD } \\
\text { Range }\end{array}$ & $\begin{array}{c}1.5 \\
0.90^{\mathrm{a}} \\
0.05 \\
0.86-0.99\end{array}$ & $\begin{array}{c}1.5 \\
0.6^{\mathrm{a}} \\
0.05 \\
0.42-0.54\end{array}$ & $\begin{array}{c}1.5 \\
1.088^{\mathrm{a}} \\
0.39 \\
0.42-1.32\end{array}$ & $\begin{array}{c}1.5 \\
0.22^{\mathrm{a}} \\
0.01 \\
0.21-0.23\end{array}$ & $\begin{array}{c}1.5 \\
1.05^{\mathrm{a}} \\
0.32 \\
0.64-1.38\end{array}$ & $\begin{array}{c}1.5 \\
0.89^{\mathrm{a}} \\
0.30 \\
0.61-1.35\end{array}$ & $\begin{array}{c}1.5 \\
0.94^{a} \\
0.26 \\
0.60-1.84\end{array}$ & $\begin{array}{c}1.5 \\
0.94^{\mathrm{a}} \\
0.27 \\
0.62-1.36\end{array}$ \\
\hline \multirow[t]{2}{*}{ Phosphate (mg/L) } & $\begin{array}{l}\text { WHO } \\
\text { Mean } \\
\text { SD } \\
\text { Range }\end{array}$ & $\begin{array}{c}50 \\
0.21^{\mathrm{a}} \\
0.01 \\
0.20-0.23\end{array}$ & $\begin{array}{c}50 \\
0.48^{\mathrm{ab}} \\
0.04 \\
0.44-0.54\end{array}$ & $\begin{array}{c}50 \\
0.57 \mathrm{ab} \\
0.01 \\
0.56-0.58\end{array}$ & $\begin{array}{c}50 \\
0.48^{\mathrm{ab}} \\
0.01 \\
0.46-0.50\end{array}$ & $\begin{array}{c}50 \\
1.95^{\mathrm{b}} \\
2.27 \\
0.71-6.00\end{array}$ & $\begin{array}{c}50 \\
1.94^{\mathrm{b}} \\
1.75 \\
0.67-5.00\end{array}$ & $\begin{array}{c}50 \\
1.72^{\mathrm{ab}} \\
0.89 \\
0.68-3.00\end{array}$ & $\begin{array}{c}50 \\
1.76^{\mathrm{ab}} \\
1.32 \\
0.69-4.00\end{array}$ \\
\hline & WHO & 0.10 & 0.10 & 0.10 & 0.10 & 0.10 & 0.10 & 0.10 & 0.10 \\
\hline \multirow[t]{3}{*}{ Sulphate (mg/L) } & Mean & $11.13^{\mathrm{a}}$ & $14.25^{\mathrm{a}}$ & $15.00^{\mathrm{a}}$ & $1.01^{\mathrm{a}}$ & $7.00^{\mathrm{a}}$ & $5.00^{\mathrm{a}}$ & $3.50^{\mathrm{a}}$ & $4.00^{\mathrm{a}}$ \\
\hline & $\mathrm{SD}$ & 0.74 & 17.77 & 19.07 & 0.07 & 2.65 & 0.00 & 3.54 & 2.65 \\
\hline & Range & $10.00-12.00$ & $3.00-45.00$ & $3.00-48.00$ & $0.90-1,10$ & $4.00-9.00$ & $5.00-5.00$ & $1.00-6.00$ & $2.00-7.00$ \\
\hline \multirow{3}{*}{ Silica(mg/L) } & WHO & 250 & 250 & 250 & 250 & $\begin{array}{l}250 \\
142 \mathrm{~b}\end{array}$ & 250 & 250 & 250 \\
\hline & $\begin{array}{l}\text { Mean } \\
\text { SD }\end{array}$ & $\begin{array}{l}3.25^{\mathrm{e}} \\
0.11\end{array}$ & $\begin{array}{l}1.44^{\mathrm{b}} \\
0.01\end{array}$ & $\begin{array}{l}1.71^{\mathrm{b}} \\
0.02\end{array}$ & $\begin{array}{c}0.76^{\mathrm{a}} \\
0.38\end{array}$ & $\begin{array}{l}1.42^{\mathrm{b}} \\
0.66\end{array}$ & $\begin{array}{c}1.38^{\mathrm{ab}} \\
0.63\end{array}$ & $\begin{array}{l}1.56^{\mathrm{b}} \\
0.64\end{array}$ & $\begin{array}{c}1.38^{\mathrm{ab}} \\
0.57\end{array}$ \\
\hline & $\begin{array}{l}\text { Range } \\
\text { WHO }\end{array}$ & $3.10-3.40$ & $1.43-1.45$ & $1.69-1.74$ & $0.10-1.00$ & $1.08-2.60$ & $1.05-2.50$ & $1.04-2.30$ & $1.06-2.40$ \\
\hline
\end{tabular}

DO-Dissolved Oxygen; EC, Electrical Conductivity; TDS, Total Dissolved Solids; T-Hard, Total Hardness; Means of the same alphabets along the rows are not significantly different $(\mathrm{p}>0.05)$. 


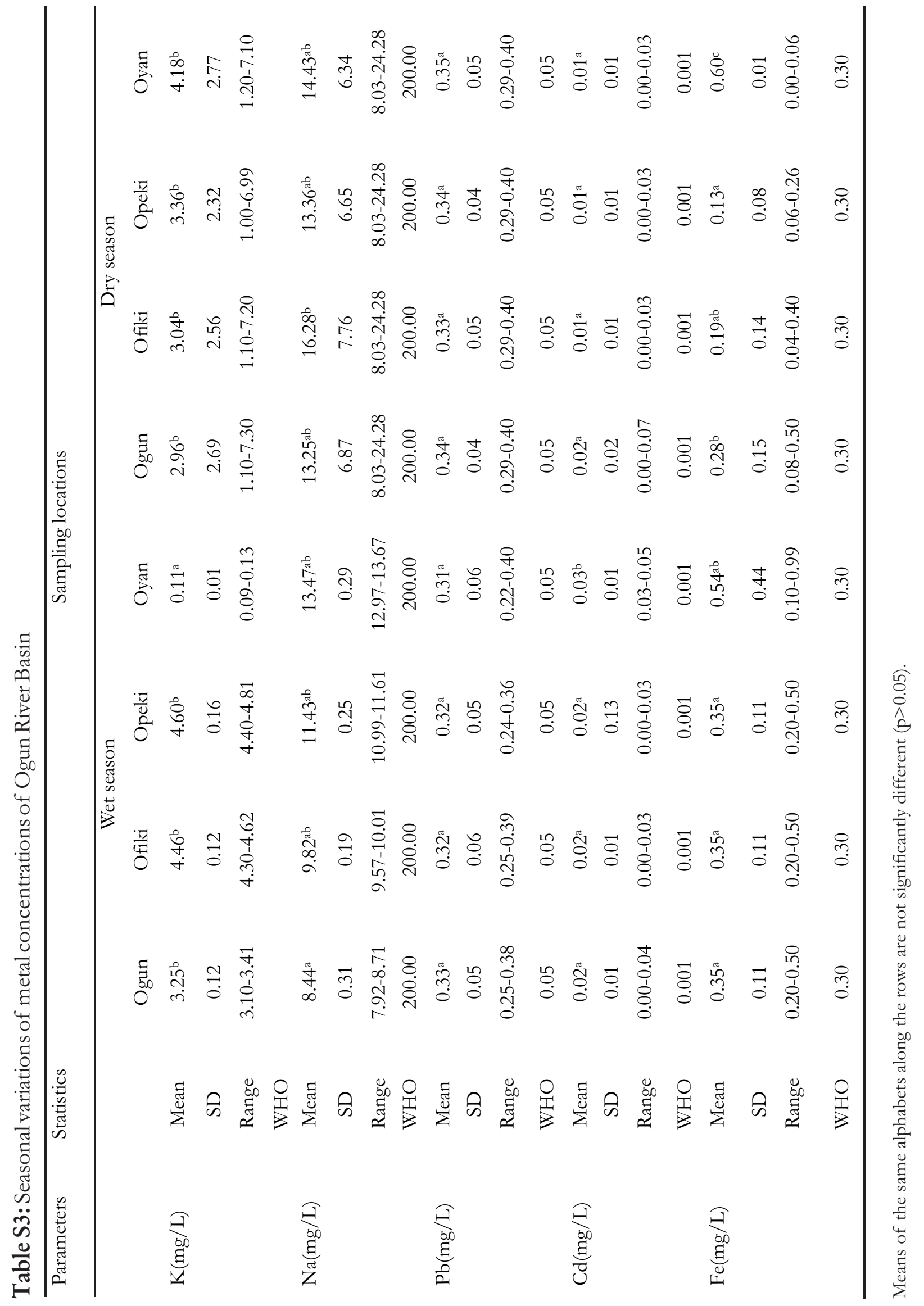

